DOI: 10.17707/AgricultForest.65.1.12

\author{
Filali LATRECHE, Mohamed BENIDIR, \\ Elhadi MECHENTEL, Khaled ABBAS, Sameh- SEBIHI ${ }^{1}$
}

\title{
ASSESSING AGRO-ECOLOGICAL AND ECONOMIC SUSTAINABILITY OF CEREALS-BASED CROPPING SYSTEMS IN SOUK AHRAS HIGH PLAINS (EAST ALGERIA)
}

\section{SUMMARY}

The food deficit that has prevailed for more than 50 years in the Algerian agricultural sector, the problem of land depletion due mainly to the regression of organic matter levels in soils generated by cereals fallow system, widely practiced in the Algerian semi-arid zones, and the evolution of the expectations of consumers, multiply to infinity the need to assess cropping systems sustainability. To reach this goal we have integrated 10 agro ecologic and economic indicators values into a global sustainability index (Sg) ranking from 0 to 1 , applying continuous non-linear sustainability functions that use thresholds defining what is sustainable, unsustainable, or intermediate. Data needed to calculate the indicators was getting from face to face interview with farmers for 140 fields practicing 6 cereals-based cropping systems (cereal worked and pastured fallow, continues cereal, cereal potatoes, grain legumes or other crops) in Souk Ahras high plains region (east of Algeria).The evaluation results showed that cereal other crops and cereal potatoes systems have a better overall sustainability despite the fact that some of the indicators can be negatively impacted. Cereal worked fallow has the lowest sustainability. The high value of economic indicators; variable cost and gross income explain the first result, poor economic performance, and inadequate soil management make that cereal worked fallow has the lowest sustainability. Cereal grain legumes system is supported by the state as part of the program of resorption of fallow; but it has an intermediate durability, with high agro ecological performances, and moderate economic sustainability due to the lack of mastery of technical itinerary.

Keywords: cropping system, sustainability, assessment, indicators

\section{INTRODUCTION}

The emergence of large-scale phenomena such as food crises and environmental degradation around the world has resulted in the appearance of the

\footnotetext{
${ }^{1}$ Filali Latreche (corresponding author: filalila84@gmail.com), Department of Agricultural Sciences, University of Farhat Abbas Sétif1 (UFAS1). Research Laboratory Sciences and Technologies of the Living, institute of agro-veterinaries University of Souk -Ahras, ALGERIA; Mohamed Benidir, Agrosystems East Division of INRA Algeria - Setif, ALGERIA; Elhadi Mechentel, Department of Agricultural Sciences, Institute of Agro-Veterinaries Sciences, University of Souk Ahras, ALGERIA; Khaled Abbas, National Institute of Agronomic Research Algers (INRAA Alger), ALGERIA; Sameh- Sebihi, professional formation center SA, Algeria.

Notes: The authors declare that they have no conflicts of interest. Authorship Form signed online.
} 
concept of sustainable development. Kane (1999), defines sustainable development as the development that meets the needs of the present without compromising the ability of future generations to meet their own needs. This new model of development is based on three main concerns: maintaining a viable economy, developing social projects and preserving the environment, resources and capabilities production (Payraudeau \&Van der Werf, 2005). The millennium ecosystem assessment report, makes out the responsibility of agriculture: i) In the removal of ground and superficial water quality (nitrogen and pesticide pollution), soil (erosion and heavy metal contamination), and air (greenhouse effect); ii) In the loss of biodiversity (homogenization of habitat, mortality due to pesticides); iii) In non-renewable resources (fossil energy, nutrients); iv) In increasing disaster risk (flooding, flows mud).

In the south of the Mediterranean, the challenges of sustainable development require greater productivity per unit of available resources (input, water, energy), production methods are more adapted to the diversity of local constraints (Meynard, 2008). In Algeria, the main challenges for the agricultural sector are: increasing crop and livestock production to cope with population growth and fill the food deficit by mobilizing more resources; these are scarce and poorly exploited (Cherif et al., 2012) meeting the social expectations by increasing the contribution of this sector to employment and provide healthy products to consumers. The crucial situation of the Algerian agriculture, accentuates the need for an evaluation of existing cropping systems in order to determine the weak points and the strengths of these systems, to re-design or design new cropping systems those satisfied farmers, agronomists, decision makers and society attention's and meet the challenges of sustainable agriculture.

In the two recent decades, many indicator-based methods for evaluating the sustainability of agricultural systems at various scales have been developed (Binder et al., 2010, Bockstaller et al., 2009, Niemeijer \& Groot, 2008). Recourse to indicators is useful for cropping systems assessment, designing and policies making at all scales of decision making. However, the development and application of suitable performance indicators to monitor change and sustainability have been subject to significant debate (Nortcliff, 2002\& Girardin et al., 2000), generally five criteria are sought in a good indicator; it must be easy to implement, immediately understandable, sensitive to the variations of cultural practices and reflecting the reality of the field (Kristle Nathan \& Sudhakara Reddy, 2010). Likewise, the choice of relevant indicators has the big importance in the evaluation process.

However, methods used for cropping systems assessments require the use of a multi criteria approach, taking into account the various components of sustainability; those methods may contain indicators that are irrelevant to the context of the region (groundwater pollution by nitrogen) or the scale of evaluation (IDEA method for farming system); and they need a parameterization and an adaptation to the local context by using a set of data which can be difficult to acquire. Differently from works that evaluate sustainability by using methods, 
the aim of this paper was the assessment of agro ecological and economic sustainability of cereals-based cropping systems using a sustainability function in a semi-arid high plains region (Souk -Ahras) in the east of Algeria, to diagnose their strong and weak points and, on this basis, to encourage discussions during the design of innovative cropping systems that will afterwards be tested in fields.

\section{MATERIAL AND METHODS \\ Study area and farms monitored}

The study was conducted in the Souka- Ahars region (east Algeria) for two years (2015 and 2016).The region was selected because of their inner diversity based on two factors (a) the diversity of the environment, particularly according to the climatic degree of aridity and vegetation distribution. There are three semiarid climate zones in the Souk- Ahras region: upper, central and lower. The average annual rainfall decreases from the upper to the lower zones (from 600 to $150 \mathrm{~mm}$ ), while the inter-annual precipitation variability increases; (b) the diversity of cultivation systems practiced despite the dominance of cereal fallow system with these different types (worked, pastured or cultivated fallow).

Cropping systems management was monitored during two years (2015,2016), by using a structured questionnaire completed during face-to-face interviews with farmers. The structured schedules included seventy seven questions, designed to collect data required to calculate indicators; to describe the function of cropping system, the economic environment and to identify potentials and constraints facing the farmers. The 140 surveyed farms belong to the median zone where the climate is less intense (precipitation oscillates from 600 to $350 \mathrm{~mm}$. They represent $2 \%$ of the total exploitation and cover a useful agricultural surface of 10688 ha. $75 \%$ of the monitored farms combine between livestock and crop production. On the other hand $25 \%$ practices only crop production.

\section{Choice of the indicators}

A set of ten indicators (table1) was selected after an extensive literature review described by Deytieux(2016), Bockstaller et al(2013), BekhoucheGuendouz (2011), and Yakhelf et al(2008).The aim of the literature review and investigation of the sustainability assessment methods was to select pertinent indicators that quantify the effects of cropping systems management on agro-ecological and on economic profitability, using data that can be easily obtained (through face-to-face interviews).

Three criteria applied in the selection of indicators: (i) data availability (inputs for indicator calculation should be easily derived from farmer); (ii) synthesis (the indicator needs to summarize various aspects of the studied area, providing a good compromise between the description of the processes and their simplification into a single value); (iii) simplicity (the indicator needs to be easily calculated and interpreted. Indicators that require direct measures on soils, or crops were excluded. 
Table 1. Agro-ecological, economic and soil management indicators used to evaluate cropping systems sustainability.

\begin{tabular}{|c|c|c|c|}
\hline indicator name & $\begin{array}{l}\text { indicator } \\
\text { acronym }\end{array}$ & indicator definition & reference \\
\hline $\begin{array}{l}\text { Treatment } \\
\text { Frequency Index }\end{array}$ & TFI & $\begin{array}{l}\text { Number of registered doses } \\
\text { of pesticides applied on a } \\
\text { parcel for one cultural } \\
\text { campaign. }\end{array}$ & $\begin{array}{l}\text { Eckert } \\
(2000)\end{array}$ \\
\hline Diversity & Div & $\begin{array}{l}\text { Minimum number of } \\
\text { cultivation to cover } 3 / 4 \text { of the } \\
\text { area of the farm. }\end{array}$ & $\begin{array}{l}\text { Turpin, } \\
(2010)\end{array}$ \\
\hline $\begin{array}{l}\text { Rotational } \\
\text { cropping }\end{array}$ & RC & $\begin{array}{l}\text { Assessed by two factors: crop } \\
\text { diversity and plot size. }\end{array}$ & \begin{tabular}{|l} 
Scholtus, \\
Bockstaller \\
(2015)
\end{tabular} \\
\hline Crop succession & CS & $\begin{array}{l}\text { Calculation at the parcel level } \\
\text { on the succession of the last } \\
\text { four years. }\end{array}$ & $\begin{array}{l}\text { Scholtus, } \quad \& \\
\text { Bockstaller } 2015\end{array}$ \\
\hline Soil Cover index & SC & 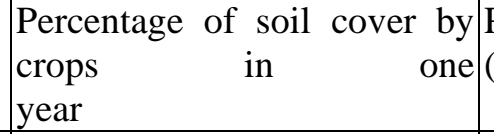 & $\begin{array}{l}\text { Pervanchon, et al } \\
(2002)\end{array}$ \\
\hline Variable Costs & VC & $\begin{array}{l}\text { Sum of the costs for gasoline, } \\
\text { lubricants, pesticides, } \\
\text { fertilisers, and seeds }\end{array}$ & - \\
\hline Gross in & GI & $\begin{array}{l}\text { Yield of harvested product } \\
\text { multiplied } \\
\text { by its price }\end{array}$ & \\
\hline Gross margin & GM & $\mathrm{GI}-\mathrm{VC}$ & - \\
\hline $\begin{array}{l}\text { Economic } \\
\text { efficiency }\end{array}$ & Ee & $\begin{array}{l}\text { Ratio between gross product } \\
\text { and total expenses multiply } \\
\text { by } 100\end{array}$ & \\
\hline \begin{tabular}{|l|}
$\begin{array}{l}\text { Energy } \\
\text { consumption due } \\
\text { to machinery }\end{array}$ \\
\end{tabular} & $\mathrm{E}_{\text {machine }}$ & $\begin{array}{l}\text { Calculated first, at the plot } \mathrm{I} \\
\text { scale, and then aggregated at } \\
\text { the farm. }\end{array}$ & $\begin{array}{l}\text { Donaldson, et al } \\
(1994)\end{array}$ \\
\hline
\end{tabular}

The indicators are grouped in tree classes (Table 2). The economic index include variable costs (VC), gross income (GI), gross margin (GM) and the ratio between VC and GI; economic efficiency (Ee). Agro ecological index consists of crop succession (CS); its goal is the assessment of the cultural successions implemented in relation to the principles of integrated production to diagnose consistency of crop systems; which can influence the outcome of the other indicators, treatment frequency Index (TFI); this indicator reflects the intensity of pesticide use for one cultural campaign. Diversity (Div); it is defined as the minimum number of cultivation to cover $3 / 4$ of the area of the farm (Turpin et al.,2010). Rather this number is high, rather the biodiversity of the farm assumed 
high. Energy consumption due to machinery ( $\left.E_{\text {machine}}\right)$; the calculation of this indicator is done by estimating the energy for each tool passage using an adapted equation developed by Donaldson et al (1994). Soil management class was represented by soil cover index (SC); assessed by two factors: crop diversity and plot size; this indicator gives an appreciation for biodiversity and landscape, and rotational cropping

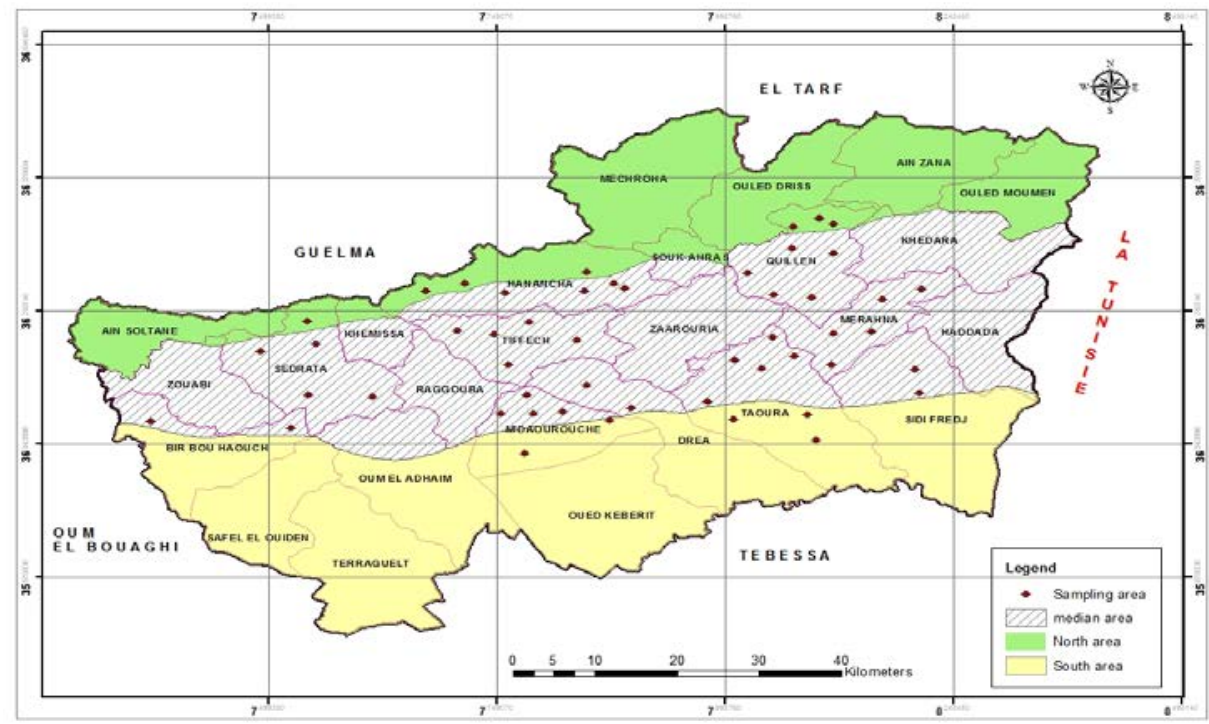

Figure 1. Location of the study area within Souk-Ahras province. 1/500000 Source: Author's own elaboration

\section{Application of the methodology}

The sustainability values of the indicators $(\mathrm{Si})$, for the 6 cropping systems ware calculated according to the sustainability function described by Castoldi, And Bechini (2010). The used parameters are given in Table 2. Whenever possible the thresholds were determined by referring to the bibliography for certain indicators (variable cost and cross margin), or using statistics from the measured distribution in the fields monitored. The assignment of the $\mathrm{K}$ value is done in such a way that the derivative of the durability function needed to be low close to the optimum range for these indicators and higher at the extremes (a variation of the indicator close to the optimum range does not affect sustainability); for that a value of k equal to 0.5 was attribute for GI. GM. Ee. and TFI. Contrarily value of $k$ equal to two was assigned to soil cover index to make variability of sustainability more pronounced and influenced by SC index.

Each Si calculated for the 140 fields were aggregated into tree values of Sc; these last were gathered into a unique index (Sg). The sets of weights used to aggregate indicators sustainability (Si) into sustainability class (Sc) (figure 2 (a)) then to global sustainability (Sc) (figure 2(b)), were defined by face-to-face 
interviews with 26 stakeholders (farmers, agronomic, researchers, agronomists, decision-makers, and environmentalists).

Table2: Parameters used to calculate the sustainability functions for the economic and agro-ecological indicators.

\begin{tabular}{|c|c|c|c|c|c|c|c|}
\hline Indicator & $\begin{array}{l}\text { indicator } \\
\text { acronym }\end{array}$ & unites & $S_{\min }$ & $\mathrm{S}_{\mathrm{optL}}$ & $\mathrm{S}_{\mathrm{optU}}$ & $S_{\max }$ & $\mathrm{k}$ \\
\hline \multicolumn{8}{|l|}{ Economic calss } \\
\hline Variable Costs & VC & DA ha ${ }^{-1}$ & - & - & 35908.3 & 43630.5 & 1 \\
\hline Gross income & GI & $\mathrm{DA} \mathrm{ha}^{-1}$ & 45308.9 & 61322.2 & - & - & 0.5 \\
\hline Gross margin & GM & DA ha $^{-1}$ & 1029.6 & 19872.9 & - & - & 0.5 \\
\hline $\begin{array}{l}\text { Economic } \\
\text { efficiency }\end{array}$ & $\mathrm{Ee}$ & $\%$ & 1.66 & 4.62 & - & - & 0.5 \\
\hline \multicolumn{8}{|c|}{ Agro ecological calass } \\
\hline Crop succession & CS & $0-7$ & 1 & 7 & - & - & 1 \\
\hline $\begin{array}{l}\text { Treatment } \\
\text { Frequency } \\
\text { Index }\end{array}$ & TFI & IFT point & - & - & 0.73 & 0.99 & 0.5 \\
\hline Diversity & Div & $0-4$ & 1 & 2 & - & - & 1.0 \\
\hline \begin{tabular}{|ll} 
Energy & \\
consumption & \\
due & to \\
machinery & \\
\end{tabular} & $\mathrm{E}_{\text {machine }}$ & MJ ha $^{-1}$ & 2493.90 & 2688.80 & - & - & 1.0 \\
\hline \multicolumn{8}{|c|}{ Soil management calss } \\
\hline \begin{tabular}{|ll}
$\begin{array}{l}\text { Soil } \\
\text { index }\end{array}$ & Cover \\
\end{tabular} & $\mathrm{SC}$ & $0-1$ & 0.38 & 0.48 & - & - & 2.0 \\
\hline $\begin{array}{l}\text { Rotational } \\
\text { cropping }\end{array}$ & $\mathrm{RC}$ & $0.5-10$ & 1 & 7 & - & - & 1.0 \\
\hline
\end{tabular}

*Smin: minimal sustainability. $\mathrm{S}_{\text {optL }}$ : Law optimal sustainability. $\mathrm{S}_{\text {optU }}$. Upper optimal sustainability. Smax maximal sustainability. K: coefficient.

\section{Indicators values}

\section{RESULTS}

The typology of the cropping system according to crop succession makes out six groups: the head of de crop rotation is always a cereal succeeded by a worked fallow, pastured fallow, grain legumes (lentils or chickpeas), potatoes, other crops (gardening) or continues cereals. The results of the calculation of ten agro-ecological and economic indicators for 140 cropping systems are presented in table 3 . The variability of the calculated indicators among succession types was moderate for the first four cropping systems, but it was very high between cereals potatoes, cereals gardening succession and the first four successions. Within succession variability was high except for the soil cover index (table 3).

Continuous cereals (Cc) was the succession with the lowest crop succession indicator $(\mathrm{CSI}=0.4)$ followed by cereals worked and pastured fallow (table 3), for the rotational cropping indicator, cereals grain legume (Cgl) 
recorded the highest values (5.5). The treatment frequency index, which represents the intensity of pesticide use for a given crop during a farming season, raises the abuse of pesticides for the cereal-gardening system (3.8) with the use of the insecticide and the fungicide and low pesticide use for the cereal - grain legume system (0.69); this shows a benign ecological effect (reduced use of pesticides) for cereal grain legume rotation. Energy consumption due to machinery varied from 2523.1 MJ ha-1 for cereal pastured fallow Cpf to 2923.1MJ ha-1 for cereals potatoes Cp.

Table 3. Average and standard deviation (in parenthesis) of indicators calculated for 140 fields monitored over two years period in Souk-Ahras region (eastern Algeria)

\begin{tabular}{|c|c|c|c|c|c|c|c|}
\hline & $\begin{array}{l}\text { Farms } \\
\text { number }\end{array}$ & $\begin{array}{c}\text { cereals } \\
\text { worked } \\
\text { Fallow } \\
\text { (Cwf) } \\
19 \\
\end{array}$ & $\begin{array}{c}\text { cereals } \\
\text { pastured } \\
\text { fallow } \\
(\mathrm{Cpf}) \\
39\end{array}$ & $\begin{array}{c}\text { continue } \\
\text { s cereals } \\
\text { (Cc) } \\
\\
38 \\
\end{array}$ & $\begin{array}{c}\text { cereals } \\
\text { grain } \\
\text { legumes } \\
\text { (Cgl) } \\
15 \\
\end{array}$ & $\begin{array}{c}\text { cereals } \\
\text { potatoes } \\
(\mathrm{Cp}) \\
6 \\
6\end{array}$ & $\begin{array}{c}\text { cereals } \\
\text { other } \\
\text { crops } \\
\text { (Coc) } \\
23 \\
\end{array}$ \\
\hline \multirow[t]{4}{*}{ (a) } & $\begin{array}{l}\text { Variable } \\
\text { Costs } \\
\text { (DA ha }^{-1} \text { ) }\end{array}$ & $\begin{array}{c}45795.2 \\
(53898.7)\end{array}$ & $\begin{array}{c}37678.7 \\
(12626.6)\end{array}$ & $\begin{array}{c}33909.1 \\
(13681.4)\end{array}$ & $\begin{array}{c}36479.4 \\
(14036.1)\end{array}$ & $\begin{array}{c}198511.9 \\
(235781.0)\end{array}$ & $\begin{array}{c}81707.7 \\
(179135.8)\end{array}$ \\
\hline & $\begin{array}{l}\text { Cross } \\
\text { income } \\
\left(\text { DA ha }^{-1}\right)\end{array}$ & $\begin{array}{c}37032.4 \\
(42505.2)\end{array}$ & $\begin{array}{c}34315.1 \\
(15538.6)\end{array}$ & $\begin{array}{c}47419.3 \\
(24513.7)\end{array}$ & $\begin{array}{c}87955.1 \\
(48720.2)\end{array}$ & $\begin{array}{l}3577120.7 \\
(5388948.4)\end{array}$ & $\begin{array}{c}211229.5 \\
(647986.2)\end{array}$ \\
\hline & $\begin{array}{l}\text { Gross } \\
\text { margin } \\
\left(\text { DA ha }^{-1}\right)\end{array}$ & $\begin{array}{c}14101.9 \\
(16598.1)\end{array}$ & $\begin{array}{c}13010.4 \\
(10531.6)\end{array}$ & $\begin{array}{c}15401.2 \\
(14375.9)\end{array}$ & $\begin{array}{c}27880.7 \\
(23228.4)\end{array}$ & $\begin{array}{c}39719.9 \\
(5153862.6)\end{array}$ & $\begin{array}{c}55056.7 \\
(124924.1)\end{array}$ \\
\hline & $\begin{array}{l}\text { Economic } \\
\text { efficiency } \\
\text { (\%) }\end{array}$ & $4.5(4.9)$ & $5.4(6.8)$ & 3.9 (3.1) & 4.1(4.7) & 48.3(71.4) & $11.4(16.8)$ \\
\hline \multirow[t]{4}{*}{ (b) } & $\begin{array}{l}\text { Crop } \\
\text { succession } \\
(0-7)\end{array}$ & $0.5(0.1)$ & $0.5(0.0)$ & $0.4(0.1)$ & $2.2(0.8)$ & 2.1(1.1) & $1.7(0.6)$ \\
\hline & $\begin{array}{l}\text { Treatment } \\
\text { Frequency } \\
\text { Index-point }\end{array}$ & $1.0(1.6)$ & $0.77(0.7)$ & $0.9(1.9)$ & $0.69(0.45)$ & $1.2(0.6)$ & 3.3(11.1) \\
\hline & $\begin{array}{l}\text { Diversity } \\
(0-1)\end{array}$ & $2.0(0.8$ & $1.8(0.7)$ & $1.9(0.7)$ & $2.53(0.83)$ & $2.7(1.0)$ & $2.0(0.7)$ \\
\hline & $\begin{array}{l}\text { Energy } \\
\text { consumptio } \\
\mathrm{n} \text { due to } \\
\text { machinery } \\
\left(\mathrm{MJ} \mathrm{ha}^{-1}\right)\end{array}$ & $\begin{array}{c}2713.08 \\
(451.1)\end{array}$ & $\begin{array}{l}2630.0 \\
(418.7)\end{array}$ & $\begin{array}{l}2676.6 \\
(542.6)\end{array}$ & $\begin{array}{l}2924.4 \\
(514.7)\end{array}$ & $\begin{array}{l}2523.1 \\
(329.0)\end{array}$ & $\begin{array}{l}2900.9 \\
(419.7)\end{array}$ \\
\hline \multirow[t]{2}{*}{ (c) } & $\begin{array}{l}\text { Soil Cover } \\
\text { index }(0-1)\end{array}$ & $0.5(0.0)$ & $0.5(0.0)$ & $0.4(0.0)$ & $0.4(0.0)$ & $0.4(0.0)$ & $0.4(0.1)$ \\
\hline & $\begin{array}{l}\text { Rotational } \\
\text { cropping } \\
\text { (1-7) }\end{array}$ & $3.0(2.4)$ & $3.1(2.2)$ & $3.4(2.2)$ & $5.5(2.6)$ & $3.8(1.9)$ & $3.8(2.2)$ \\
\hline
\end{tabular}

(a)Economic indicators. (b) Agro-ecological indicators. (c) Soil management indicators 


\section{Sustainability values.}

\section{Variability within crop succession types}

With the exception of cereal pastured fallow and cereal potatoes, the variability of sustainability within succession types was low (figure 3). This was predictable because of narrow variability in the indicator values (table 3) and the similarity of crop management.

\section{Comparison the global sustainability according to crop succession}

Despite having substantial differences in all economic indicators, cereal potatoes have the biggest value for the economic sustainability (figure2 a), and therefore it holds the highest durability (figure 2 b). For soil management (represented by crop succession and soil cover index), Cpf was the best succession type, the other successions have low sustainability values (lower than 0.34). However, for agro ecological indicators, $\mathrm{Cgl}$ has the biggest sustainability (0.69) with very high diversity and crop succession (figure 2a), These results can be explained by close values of indicators constituting this scale of sustainability; this scale has the worst values of durability, with values of Sc reaching zero for some fields.

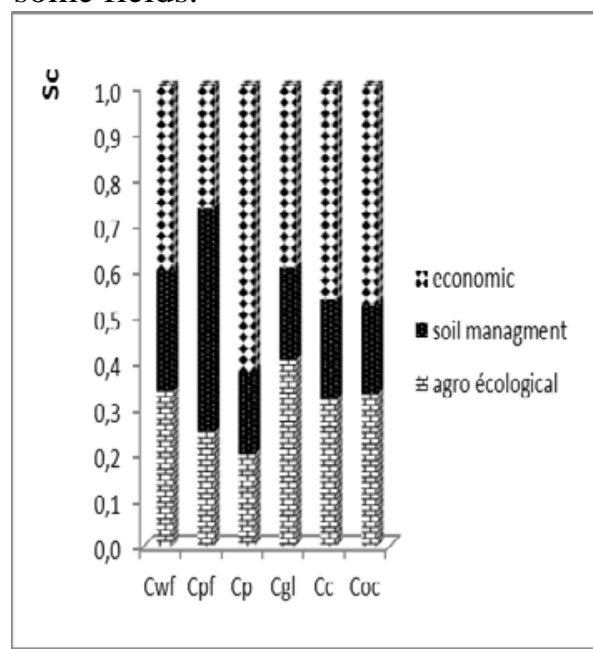

a)

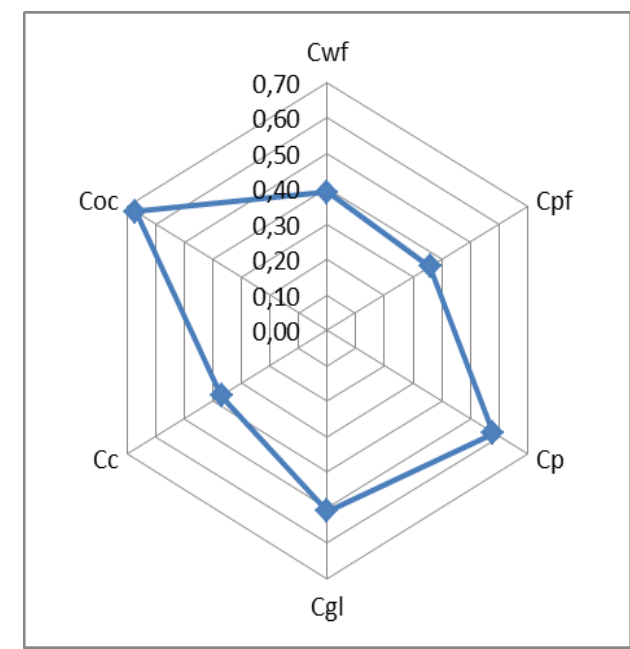

b)

Figure 2. a) Contribution of each indicators classes to global sustainability:

Cwf: cereal worked fallow. cereal pastured fallow. Cp; cereal potatoes. Cgl; cereal grain legums Cc; continues cereal and Coc; cereal other crops) b) global sustainability for the 6 cropping system.

\section{Weighted global sustainability index}

As indicated in the methodology the global sustainability index Sg was calculated according to the sets of weights (researchers. agronomists. ecologists. decision-makers. and farmers.). The resulting rankings of the six cropping systems are reported in table 4. 
Indicators

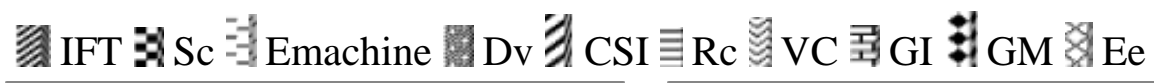
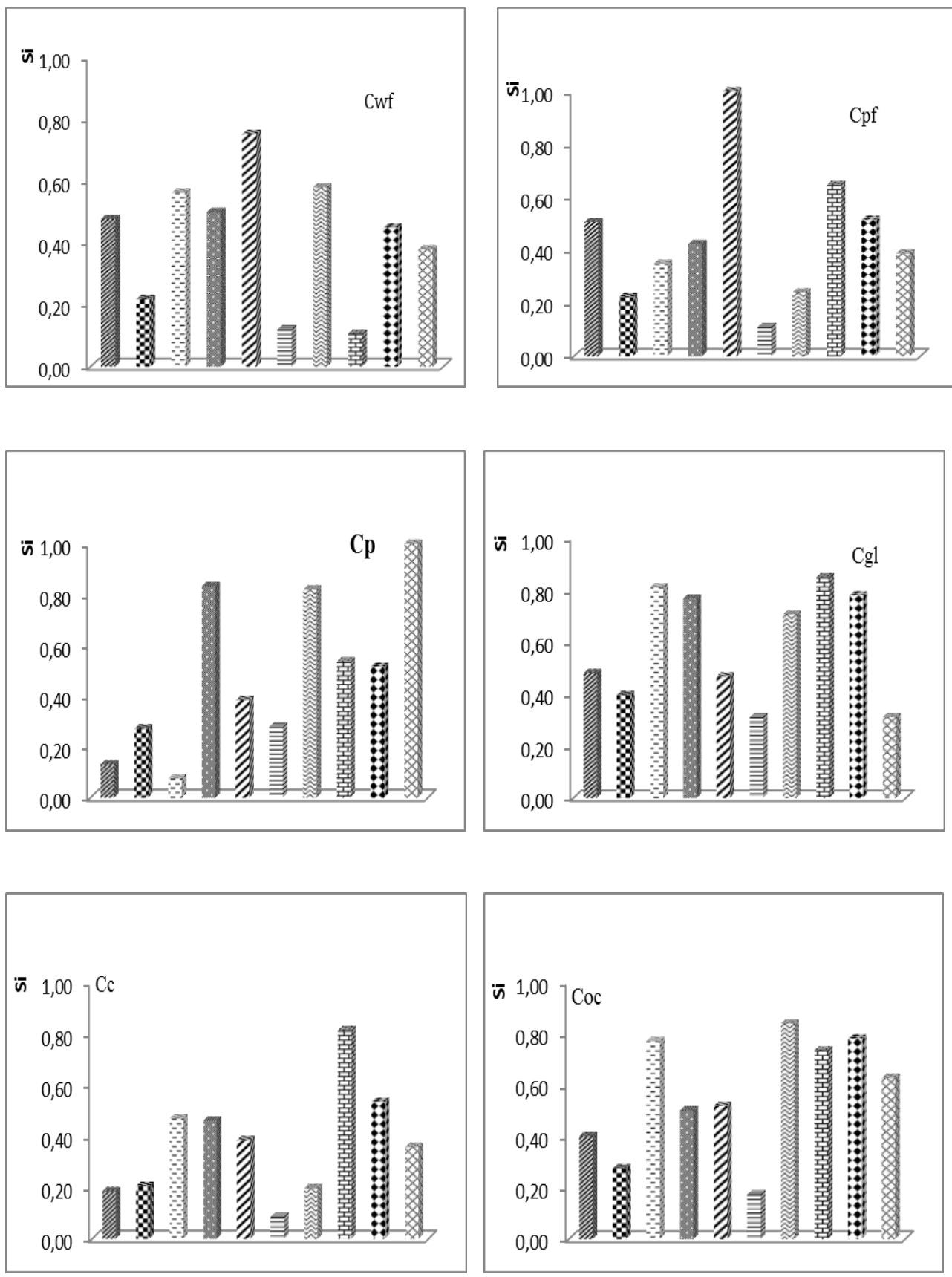

Figure 3: Contribution of the indicators to the global sustainability index (Sg) for the six cropping systems. 
Table 4: Ranking of six crops successions types based on global sustainability index (Sg) calculated with six different sets of weights.

\begin{tabular}{|c|c|c|c|c|c|c|c|}
\hline stakeholders & $\begin{array}{c}\text { equal } \\
\text { weights }\end{array}$ & researchers & agronomists & Ecologist & $\begin{array}{c}\text { decision- } \\
\text { makers }\end{array}$ & farmer & $\begin{array}{c}\text { Average } \\
\text { rank }\end{array}$ \\
\hline $\begin{array}{c}\text { cropping } \\
\text { systems }\end{array}$ & 3 & 3 & 3 & 2 & 3 & 1 & 2.5 \\
\hline $\begin{array}{c}\text { cereals } \\
\text { worked } \\
\text { Fallow }\end{array}$ & 1 & 5 & 4 & 4 & 2 & 3.5 \\
\hline $\begin{array}{c}\text { cereal } \\
\text { pastured } \\
\text { fallow }\end{array}$ & 5 & 2 & 1 & 1 & 2 & 3 & 1.8 \\
\hline $\begin{array}{c}\text { continues } \\
\text { cereals }\end{array}$ & 2 & 5 & 6 & 3 & 6 & 4 & 4.2 \\
\hline $\begin{array}{c}\text { cereals grains } \\
\text { legumes }\end{array}$ & 1 & 6 & 2 & 6 & 1 & 6 & 4.5 \\
\hline $\begin{array}{c}\text { wheat } \\
\text { potatoes }\end{array}$ & 6 & 4 & 4 & 5 & 5 & 5 & 4.7 \\
\hline $\begin{array}{c}\text { cereals other } \\
\text { crops }\end{array}$ & 4 & 5 & & & & \\
\hline
\end{tabular}

For agronomist due to the larger weight assigned to the agro ecological and soil management indicators, cereal grains legumes was ranked in the first; likewise cereal potatoes was ranked in the first by farmers decisions makers and ecologist this ranking is due to the high weight attributed to economic indicators. Depending on the weights the cereal other crop successions were given different rankings by different stakeholder groups. Continuous cereal is the worst system with an average ranking equal to 1.8 (normally scored very poorly, due to low values for most indicators) followed by cereals worked fallow. Contrariwise, cereal rotated with other crops was ranked fifth by researchers, ecologist decision-makers and farmers, due to a better economic and agro ecological performance of other crops, while for the other stakeholders it was fourth.

The contribution of the 10 indicators to the global sustainability index Sg is reported in Figure3. It appears that variability of cropping system sustainability among crop successions is moderate due to difference existing in the mode of production which influences the value of indicator, and weights attributed by some stakeholder (table 4). For farmers for example: coefficient of variation of $\mathrm{Sg}=17 \%$ ), while for other groups it was higher (researchers 27, agronomists. $30 \%)$. According to the assigning weights the lowest average Sg (0.55) was calculated for agronomists and the highest (0.61) for researchers, decisionmakers and ecologists.

\section{DISCUSSION}

\section{Thresholds for the sustainability functions and stakeholder groups}

It is clear that a large degree of uncertainty was inherent in our analysis. The choice of thresholds made sustainability functions somewhat subjective 
using the median and the quartiles. The verification of the adaptability of the sustainability equation was done by re-recalculating ranks of the 6 crop successions by defining Smin. and Smax. using the 10th and 90th percentiles as a substitute of first and $3^{\text {rd }}$ quartile. We always find that $\mathrm{Si}$ was higher (using the new thresholds) in the partially sustainable range compared to the case when the old thresholds were used; likewise Sg was always equal or higher with the new thresholds (data not shown).Continues cereal remained the worst succession for most stakeholder groups. Cereal worked fallow has an intermediate position among the six cropping systems.

From all that is said, it turns out that the choice of thresholds is a delicate and decisive phase that requires further research to carry out a task of evaluation of the sustainability of cropping systems. Statistical distribution of the indicators is a common practice for determining maximum values of indicators. For example, Reig-Martinez et al.(2011) recommend the use of values that are consistent with the context and performance of cropping systems taking into account the statistical distribution, and the standards of the region where the evaluation takes place. Liebig et al.(2001), defined the optimum value as the highest (or lowest depending on the type of indicator) value measured in the population. The strong point of this method is the use of quartiles to set thresholds as it was the case for the agro- ecological index (except the crop succession indictor), for the economic index (except economic efficiency) and for the soil index management (except rotational cropping indicator),thus giving a more or less different distribution of Sc; which is the result of the compensating effect between the indicators constituting the three sustainability indexes (economic. agro ecological an soil management). For example, potatoes and other crop (vegetable) required high economic inputs (and therefore had low $\mathrm{Si}$ for VC), but giving high Si for GM. This provided a good value of Sc for cereal potatoes and cereal other crops (Figure 3),which was not too different compared to that calculated for cereals grains legumes Cgl. Among classes we can make distinction between "very good ", "good", "moderate” and "bad" systems according to values obtained for each class by using quartile limitation

\section{Comparison of crop successions}

From the 6 cropping systems, cereal other crops and cereal potatoes are the leading systems, with a very high economic income due to the added value of the vegetables and potato given by price fluctuation in favour of the farmers over the past few years. The second year of cereal, which is durum wheat the technical itinerary, includes only one or two passes through the disc harrow to have finally yields higher than three to five faith to national average (Benniou \& Aubry,2012) , farmers are aware of the draining effect of the potatoes and vegetables; they bring in high amounts of fertilizers and organic matter; they have low surface in the land if they do not rent land to produce the potato. The compensation effect is very clear between a high pressure of the pesticide recommended to control diseases (the seasonal potato and vegetables are susceptible to diseases especially fungal diseases for potatoes and pest for vegetables).( Rousselle \& Ropert, 1996) 
and the consumption of energy in the potato crop and the gross margin provided by this crop. In our study the number of farms that practice potato cultivation is low (6) because this culture is very demanding in terms of financial and water resources, the installation of an irrigation network (irrigated perimeter) and the use of local seeds can change the situation in the coming year.

In terms of abundance, cereal pastured fallow systems (39 farms) and continues cereals (38 farms) occupy the lion's share of the surveyed farms. Fallow is an integral part of the systems cereals-sheep production in the semi-arid zone, characterized by fragile soils and limited rainfall. The share of the worked fallow decreases while that of the pastured fallow increases and would represent $9 \%$ of the total forage supply (Abbas \& Abdelguerfi, 2005). On the sustainability side, this system ranks fourth after $\mathrm{Cp}$, Coc and $\mathrm{Cgl}$, and it is characterized by low economic performance.

The continuous cereal is concentrated in the farms that rent the land or that work in association with the owners of the land this rotation is in this case imposed by the owner. Low yield which results in a low economic performance, massive recourse to pesticides (herbicide), low contribution to employment, a very low diversity, a rather low rate of soil cover in winters are the most characteristics of this system, the conjugation of those factors make this system at the least in terms of sustainability (table 3 . figure 2b). Land tenure is therefore the guarantor of the continuity of this system and not their agro-ecological or economic performances.

The cereal grain legumes system occupies the third place and shows agro-ecological and economic performances (figure3). The first year, the cereal is conducted by a summary manner; with a deep tillage, P.K fertilizers, surface tillage and a nitrogen fertilization of $120 \mathrm{~kg}$ on average (Benniou \& Aubry,2012) the second year, the legume is also conducted in a summary manner; the poor economic performance of the cereal legume system is justified by low yields of legumes, despite the high price of grain legumes ( Daoudi, \& Wampfler 2010). Agro-ecological effects appear in the following year related to a minimum tillage and a reduction of the nitrogen fertilization. The fallow reduction program adopted by the state which aims to replace fallow land with a grain legume in order to improve the value of agricultural land, favourite the adoption of this system by the farmers; while lack of mastery of the legume's technical itinerary, seed shortage and lack of appropriate harvesting equipment can hinder the sustainability of the system.

Although fallow has been rotated for purely agronomic purposes (Sebillotte, et al 1993) whose main purpose is to conserve moisture, but this role is conditioned by soil depth, precipitation volume and plowing. Worked fallow only allows water storage (more than $60 \mathrm{~cm}$ ) if spring tillage is carried out sufficiently early (January-February); before the onset of drought and only if the soil is heavy (clay) and quite deep; in addition re-cropping is essential if rain is late to reduce the effect of weeds and creates mulch. However these conditions are not often met in the Algerian cereal zones characterized by low and irregular 
rainfall and especially by shallow soils (Fenni 2013; Abbas \& Abdelguerfi, 2005). This is reflected in low economic efficiency in our study, which is the result of poor performance. The excess of yield linked to the fallow cannot cover the year of fallow. If we calculate the average of the economic gains over the two years of the rotational cereals worked fallow the economic efficiency becomes 2.25 , the lowest values compared to the others.

\section{CONCLUSIONS}

This paper introduced a novel method to assess and systematically compare cropping systems, this method is based on sustainability function; its application was demonstrated for 6 cereals - based cropping systems in Souk Ahras high plains (east Algeria). The highest sustainability was assigned to cereal other crops, followed by cereal potatoes system; due to good economic performance (high incomes). However both systems have low agro $\neg$ ecological sustainability due to increased pesticide use and high energy consumption and treatment frequency; high values of these indicators affect negatively durability. The cereal grain legumes system has a good durability increased by the agro ecological effect linked to the introduction of a leguminous in the rotation. This system is very appreciated by the farmers, in addition it concord with the strategy of the State which aims is to replace fallow land with a grain legume. Cereal pastured and worked fallow have low durability with a priori for cereal pastured fallow; but the edapho climatic conditions, the socio-economic context and the vocation of the region ensure the persistence of these two systems.

\section{ACKNOWLEDGMENTS}

We would like to kindly acknowledge the contribution of all the farmers interviewed during this work for their time and their patience during the sometime tedious work of data collection over two years. We also thank the stakeholders interviewed

\section{REFERENCES}

Abbas, K. \& Abdelguerfi, A. (2005). Perspectives d'avenir de la jachère pâturée dans les zones céréalières semi-arides. Fourrages. 184 : 533-546.

Bekhouche-guendouz, N., (2011). Evaluation de la Durabilité des Exploitations Bovines Laitières des Bassins de la Mitidja et d'Annaba. National Polytechnic Institute of Lorraine and National School of Agronomy (Algeria) Ph.D Thesis. pp. 310.

Benniou, R.\& Aubry, C. (2012).Farm diversity and crop growing practices in semi-arid regions: A case study of the Setif high plains in Algeria. African Journal of Agricultural Research, 7:(48) 6363-6375. DOI: 10.5897/AJAR09.603.

Binder , R.C. , Feola, G. J., \& Steinberger, K. (2010). Considering the normative. systemic and procedural dimensions in indicator-based sustainability assessments in agriculture, Environmental Impact Assessment Review. 30: 71-81 DOI: 10.1016/j.eiar.2009.06.002.

Bockstaller, C., M. Cariolle, M.B. Galan, L. Guichard. et al., (2013). Evaluation agrienvironnementale et choix des indicateurs : acquis, enjeux et pistes. Innovations Agronomiques. 31:1-14. 
Bockstaller. C., L. Guichard. O., Keichinger, P. Girardin, M. B. Galan, and G.Gaillard, (2009). Comparison of methods to assess the sustainability of agricultural systems, a review. Agronomy Sustainable Development, 29:223-235. DOI: 10.1051/agro:2008058.

Castoldi, N. \& Bechini, L. (2010). Integrated sustainability assessment of cropping systems with agro-ecological and economic indicators in northern Italy. Europeen Journal of Agronomy. 32 : 59-72. DOI:10.1016/j.eja.2009.02.003. 175061/2/207.

Cherif, O., Jean-yves, M. \& Arlene, A. (2012) . L'agriculture algérienne face aux défis alimentaires. Trajectoire historique et perspectives». Revue Tiers Monde. 2 :123141 .

Daoudi, A. and B. Wampfler, (2010). Le financement informel dans l'agriculture algérienne : les principales pratiques et leurs déterminants. Cahier d'Agriculture. 19: 43-48. DOI : 10.1684/agr.2010.0414.

Deytieux, V., Munier-jolain N. \& Caneill, J. (2016). Assessing the sustainability of cropping systems in single- and multi-site studies. A review of methods. Europeen. Journal of Agronomy.72: 107-126. DOI: 10.1016/j.eja.2015.10.005.

Donaldson, J.V.G., Hutcheon J.A. \& Jordan, V.W.L. (1994). Evaluation of energy usage for machinery operations in the development of more environmentally benign farming systems. In Aspects of Applied Biology. 40: 87-90.

Eckert, H., breitschuh, G. and Sauerbeck, D.R. (2000). Criteria and standards for sustainable agriculture. J. Planet Nutrient . Soil Science. 163 :337 -351 .DOI $: 10.1002 / 1522-2624$.

Fenni, M. (2013) .Impacts of climate change on cereal production in the setif high plains (north-east of algeria). Impacts and Solutions to Global Warming. 1:225-231 DOI :10.1007/978-1-4614-7588.

Girardin, P., Bockstaller, C. and Van der werf, H. (2000). Assessment of potential impacts of agricultural practices on the environment: the AGROECO method

Environement. Impact Assessment. Review,20: 227-239. DOI: 10.1016/S01959255(99)00036.

Kane, M. (1999). Sustainability Concepts: from theory to practice in Elgar.E (Ed.) Köhne. J. Gowdy. J. Henterberger. F. Straten. J.V. Sustainability in question: the search for a conceptual framework (advances in ecological economics) bookcraft(Bath)Ltd Publishers pp. 15-31.

Kristle Nathan, H. S. \& Sudhakara Reddy, B. (2010). Selection Criteria for Sustainable Development Indicators. Indira Gandhi Institute of Development Research, Mumbai available at http://www.igidr.ac.in/pdf/publication/WP-2010-013.pdf.

Liebig, M.A., Varvel, G.E. \& Doran,J. (2001). A simple performance-based index for assessing multiple agroecosystems functions. Agronomy. Journal 93 : 313-318. DOI: $10.2134 /$ agronj 2001.932313x.

Meynard, J.M. (2008). Produire autrement :réinventer les systèmes de culture in Reau. R\& Doré T. Système de culture innovant et durable. (pp11-27) Educagri Publisher. France.

Niemeijer, D.\& Groot, R.S. de(2008). A conceptual framework for selecting environmental indicator sets . Ecological indicators. 8:14- 25 DOI: 10.1016/j.ecolind.2006.11.012.

Nortcliff, S. (2002). Standardisation of soil quality attributes Agriculture. Ecosystems and Environment. 88:161-168 .PII: S0167-8809(01)00253-5. 
Payraudeau S., Van der Werf H. M.G. (2005) . Environmental impact assessment for a farming region: a review of methods, Agriculture, Ecosystems and Environment 107: 1-19.

Pervanchon, F., Bockstaller C. \& P. Girardin, (2002). Assessment of energy use in arable farming systems by means of an agro-ecological indicator: the energy indicator. In Agricultural Systems. 72: 2 149-172 .DOI:10.1016/S0308521X(01)00073-7.

Reig-Martinez, E., Gomez-limon J.A. \& Picazo-tadeo, A.J. (2011). Ranking farms with a composite indicator of sustainability. In Agriculture Economic 42: 561-575. DOI.10.1111/j.1574-0862.2011.00536.x.

Rousselle, P. \& Ropert, Y. (1996). La pomme de terre production amélioration. ennemis et maladie utilisation Crosnier J.C publisher.pp.625.

Scholtus, M.T. \& Bockstaller, C. (2015). Using indicators to assess the environmental impacts of wine growing activity: The INDIGO ${ }^{\circledR}$ metho. In European Journal of Agronomy. 62 :13-25 DOI: 10.1016/j.eja.2014.09.001.

Sebillotte, M., Allain, S. Dore T. \& Meynard, J.M. (1993). La jachère et ses fonctions agronomiques. économiques et environnementales. Diagnostic actuel». Le Courrier de l'Environnement. 20 :11-21.

Turpin, N., Stapleton, L. Perret. E., Van der heide C.M et al., (2010). Assessment of multi-functionality and jointness of production. In: Brouwer F., Van Ittersum. M.K. (eds.). Environmental and agricultural modelling: integrated approaches for policy impact assessment. Dordrecht : Springer Publisher. pp. 11-35.

Yakhelf, H., FAR. Z., Ghozlane. F., Madani, T. \& Marie, M. (2008). Evaluation de la durabilité des systèmes agropastoraux bovins dans le contexte de la zone semiaride de Sétif (Algérie). NEW MEDIT. no. 4/2008. 